\title{
Rhetoric, Accounting and Accountability: COVID-19 and the Case of Italy
}

\author{
Lorenzo Gelmini $^{1}$, Valentina Minutiello ${ }^{2, *}$, , Patrizia Tettamanzi ${ }^{2}\left(\mathbb{D}\right.$ and Maurizio Comoli ${ }^{1}$ \\ 1 Department of Economics and Business Studies, University of Eastern Piedmont, 28100 Novara, Italy; \\ lorenzo.gelmini@uniupo.it (L.G.); maurizio.comoli@uniupo.it (M.C.) \\ 2 School of Economics, Cattaneo University (LIUC), 21053 Castellanza, Italy; ptettamanzi@liuc.it \\ * Correspondence: vminutiello@liuc.it; Tel.: +39-3341910201
}

Citation: Gelmini, L.; Minutiello, V.; Tettamanzi, P.; Comoli, M. Rhetoric, Accounting and Accountability: COVID-19 and the Case of Italy. Sustainability 2021, 13, 4100. https:/ / doi.org/10.3390/su13084100

\section{Academic Editors:}

Isabel-María Garcia-Sanchez, Filippo Vitolla and Nicola Raimo

Received: 21 March 2021

Accepted: 1 April 2021

Published: 7 April 2021

Publisher's Note: MDPI stays neutral with regard to jurisdictional claims in published maps and institutional affiliations.

Copyright: (c) 2021 by the authors. Licensee MDPI, Basel, Switzerland. This article is an open access article distributed under the terms and conditions of the Creative Commons Attribution (CC BY) license (https:/ / creativecommons.org/licenses/by/ $4.0 /)$.

\begin{abstract}
The current dramatic context of COVID-19 has urged academics and practitioners to tackle the topic of the pandemic not only regarding its medical side but from the perspective of social sciences, accounting and accountability as well. In this sense, our paper moves from the pivotal work of Higgins and Walker (2012) and Merkl-Davies and Brennan (2017) and tries to trace the use and the extent of accounting communication by companies during the peculiar context of the pandemic. Considering the nature of the elements to be evaluated, we applied a manual content analysis, a more suitable technique than software to capture subjective and emotional elements. Among the main preliminary results of the paper, the volume and the importance of emotional content come to the surface, such as self-assessment and emotional tone. The paper confirms the important role of rhetorical analysis in understanding the quality and the meaning of the information provided by companies and contributes to the stream of Critical Discourse Analysis (CDA) studies on corporate reporting.
\end{abstract}

Keywords: rhetoric; content analysis; accounting communication; Critical Discourse Analysis; Italy; pandemic; non-financial information

\section{Introduction}

Since late 2019, the novel coronavirus Sars-Cov-2 has become a global pandemic, affecting almost all countries around the world and forcing governments to face difficult trade-offs, given the health, economic and social challenges it raises.

An assessment of the economic impacts of COVID-19 becomes essential for policymakers but challenging at the same time, as this crisis has unfolded with extreme speed, creating an enormous uncertainty shock [1].

Additionally, a comparison with previous crises shows significant limitations, given the unprecedented scale and multi-faceted nature of the COVID-19 crisis [2]. In fact, the current crisis is characterized by several peculiarities in terms of severity, duration and impact [3]. Moreover, it affects the entire society, provoking a general condition of immobility.

For many companies, the level of uncertainty about the future economic outlook poses a significant challenge when making estimates, as it requires a continuous exchange of information with their stakeholders, from workers to shareholders.

In this scenario, it becomes relevant to pay attention to the issue of social sustainability. Although it has only recently been addressed in the literature [4], it becomes central in a crisis context such as the current one due to its important implications in terms of risk and safety. In fact, "safety and security for humans and non-humans is the fundamental requirement of sustainability and social sustainability" [4].

In addition, the role of companies' communication has become crucial and is not only related to the exchange of information, but also to establish and maintain relationships with stakeholders by informing them about outcomes and events [5-7]. Since during the 
pandemic, the disclosure on COVID-19 concerns, for the most part, the social impacts, it seems natural to deal with sustainability from the point of view of social safety and risk.

To guarantee their survival during the current crisis, companies must pay attention to one factor: the relationship with their stakeholders. Corporate reputation is highly affected by stakeholders' perception of companies' contribution to the global crisis. Consequently, they need to provide a well-articulated disclosure on how they manage the crisis and they need to develop corporate narratives for the crisis to confirm a positive image of the organization and mitigate the possible negative reactions from the stakeholders [8].

Dialogue between corporations and shareholders is traditionally based on both formal and informal documents: examples of the former may be financial, social and environmental reports, while the latter consists of a plethora of different media releases [9].

The principal-agent models (i.e., Agency Theory) also support the importance of these continuous exchanges of information. Moreover, the recent economic, social, and environmental challenges have contributed to the spread of non-financial accounting disclosures, with the aim of probing corporations' compliance [10]: in this scenario, legitimacy theory plays the role of a justifiable factor for the disclosure of related information.

Moving from the premise that communication plays an important role within business organizations in managing the relationship with internal and external stakeholders [4-6], the aim of the paper is to provide a first, even if preliminary, insight into how companies use accounting communication during the peculiar context of the COVID-19 diffusion to maintain a positive image of themselves with stakeholders and/or repair it by mitigating possible negative reactions. In fact, a gap in previous literature is that it has analyzed corporate communications as independent texts, without considering the relevant impact of the contexts within which such communications are produced [11]. Moreover, there is the need to analyze not only the texts but also other factors-such as how the text is used by companies, the connections with other texts, the current context in which it is developed-that can have a great impact on it. Another purpose is to determine the extent to which companies have addressed the issue of the pandemic. Furthermore, it answers the call made by [12] for empirical contributions on the relationship between impression management, rhetoric and discourse and by [13] on the need for a critical perspective on how discourses and narratives are constructed. In particular, the paper tries to answer the following research questions.

RQ1: What corporate narrative and linguistic approaches are used by companies during the COVID-19 pandemic?

RQ2: How do organizations persuade their shareholders and stakeholders to support them in times of crisis and change?

Therefore, this paper explores the narrative and linguistic approach used by a sample of 190 Italian-listed companies to describe the pandemic and its consequences by focusing on the minutes of the 2019 budget approval meetings as the level of analysis. The interpretation of the results is made on the basis of the Aristotelian concept of persuasive rhetoric and its three elements: $\log o s$ (reason), ethos (credibility), and pathos (emotion). Then, we applied the Critical Discourse Analysis (CDA) to a specific case study (Brunello Cucinelli) for a systematic and detailed investigation of the dialectics used for describing the pandemic. We decided to refer to this technique because of its focus on the use of impression management during controversial issues and events, as the spread of COVID-19.

The companies of our sample prepared their financial statements according to the IAS/IFRS international accounting standards. However, our work does not take into consideration these (formal) accounting standards: they do not constitute, in fact, the basis for our research, which deals with the minutes of the assembly and not with the accounting standards. Having said that, however, we recall that there are, of course, some specific IAS/IFRS standards devoted to addressing contingent liabilities and risks, as COVID-19 has been, but the accounting standards do not apply to the discourses engaged in the shareholders' meeting. We also believe that our paper addresses the needs of both the groups of primary and secondary users, since the picture of COVID-19 plays a central role 
both for some of the primary (employees) and the secondary (community); furthermore, the narrative tactics adopted have been the same for both of them.

Italy has been among the first countries to be severely struck by the pandemic, which has dramatically explicated its effects first of all at the sanitary level and then on the economy. Precisely the impact and the relevance of the pandemic, even in economic terms, have encouraged us to investigate the Italian case; at the same time, however, given that the authors of this manuscript are Italian, we do not intend to veil the emotional content, involvement and personal relevance of this tragedy.

The remainder of the paper is structured as follows. Section 2 provides a brief literature review on the topic; Section 3 examines the sample, describes the method and presents the results of the research. Finally, Section 4 offers some concluding remarks.

\section{Literature Review}

\subsection{Social Accounting Communication and the Use of Rhetoric during a Crisis}

While the accounting and accountability literature regarding pandemics is quite limited [14,15], abundant papers and studies tackle the subtle, elusive and complex relationship between narratives in the reporting field and linguistics, with specific reference to rhetoric $[7,12,16]$.

There is a long history of narratives of social accounting starting from the 1970s [17]. Research on social accounting communication has referred to rhetorical studies to analyze communication made by business organizations and NGOs $[12,18,19]$. In particular, it has highlighted that persuasive accounting communication is used by organizations to affect audiences' perception about organizational actions, policies, or performance [20]. Furthermore, this can also help reduce the external pressures exerted by the various stakeholders to adopt responsible behavior with reference to social and environmental problems [21].

In addition, much of the recent research has focused, above all, on Corporate Social Responsibility (CSR) communication, applying different theories and approaches [13,22-28]. Subsequently, there is not a clear understanding of the rhetorical behavior applied by companies in the communication process [29].

Rhetoric can be considered synonymous with a discourse with the purpose of persuasion [30] and is often used interchangeably with ideology [12]. It is "a common process whereby people, with or without formal training, place themselves in relation to a topic and an audience to determine the facts of events in the past, to deliberate the needful actions to be taken in the future, or to acknowledge important public matters in the present" [31]. Burke [32] stated that "whenever there is persuasion, there is rhetoric. And wherever there is meaning, there is persuasion". However, in some cases, companies have applied rhetorical strategies to deviate the audience's attention from controversial activities [33].

In the past, academic research on rhetoric focused on identifying the impact of language on how the readers think, feel, or act [12]. For instance, some studies investigated the use of language in different contexts by referring to the Aristotelian concept of persuasive rhetoric [12,34-36]. More in detail, classical rhetoric consists of three Aristotelian elements, ethos (credibility), logos (reason), and pathos (emotion), which combined together in an inseparable way are able to reveal the features of a good argument and to identify the dimensions of a persuasive appeal [37]. These studies showed that in any written document, it is always possible to observe the three elements (ethos, logos, pathos) that represent intersecting dimensions of persuasive messages [38]. For instance, [39] observed that executive letters from companies belonging to different industries use the three Aristotelian elements simultaneously. In particular, logos and ethos were used for providing justification arguments, while pathos is useful for communicating appreciation and positive prospects. The study of [36] aimed at identifying the presence of differences between English and Chinese letters for trade fair invitations. He found that the English letters mainly referred to the logos element, while the Chinese letters used a combination of all three elements. The use of rhetoric within accounting communication is particularly 
present in case of crisis or significant changes for organizations that need the support of stakeholders. Reference [40] referred to rhetoric and institutional theory to study the rhetorical strategies of logos, ethos and pathos in the presence of takeovers.

A few studies have investigated CEOs' letters by applying the Aristotelian concept of persuasive rhetoric $[8,38,41,42]$. In these letters, the element logos refers to how writers logically present problems, support arguments and suggest conclusions. The element pathos concerns how writers focus on the readers' values and directly involve the readers in providing an answer, while the element ethos regards the writers' authority and integrity [41]. For instance, [8] conducted a study to identify corporate narrative strategies during the spread of COVID-19 in the hospitality sector. They performed a content analysis of CEO letters published by hospitality companies during the COVID-19 outbreak because of the crucial role played by the CEO in promoting corporate image and reputation $[43,44]$. Moreover, CEO letters should contain the companies' responses to the crisis [45]. Their findings showed an aggressive use of appeals in COVID-19 corporate narratives made by companies and of assertive tactics to build their character as responsible, competent and virtuous during the crisis. They tried to obtain support from the audience by describing their vulnerability.

In the 20th century, it was possible to find a further development of the classic rhetoric called the New Rhetoric movement [46-49]. It emphasized the relevance of context and considered three elements: the speaker/writer, the audience, and the purpose of communication. More recently, Kenneth Burke, one of the most prominent among contemporary rhetorical thinkers, extended the concept of rhetoric, by including any typology of spoken and written discourse, together with non-verbal elements [12].

In organization studies, there is a tendency to view rhetoric in a pejorative sense [50], for example, if it is used with the purpose of obfuscating or misdirecting others, while in communication studies rhetoric is seen as the core of everyday interaction and communication. Academic research on corporate narrative reporting highlighted the presence of the persuasion element within corporate communication, in particular regarding social and environmental disclosure. It renamed the concept of persuasion as "impression management", referring to the managerial manipulation of stakeholders' perceptions and thinking about social and environmental performance and organizational legitimacy and changes made by companies [51-56]. Managers use corporate narrative documents as a strategy for imposing their perspective about the organization's activities and outcomes [20,57] and the industry in which it operates $[58,59]$ or again about some issues that impact the reputation of the organization such as climate change, environmental impact, human rights [60].

At the basis of the search for legitimacy there is the presence of interaction between organizations and the environment and the scarcity of available resources, an aspect that requires drawing the attention of those who control and can dispose of resources, such as potential investors. For example, a study conducted in the context of the chemical industry highlighted that positive environmental disclosure can be used by companies for obtaining a legitimating effect on investors [61]. An alternative explanation lies in institutional theory, which emphasizes the need for organizations to respect the institutional pressures they receive to remain credible [61]. In this sense, the paper of [62] investigated the level of compliance of a sample of state-owned enterprises (SOEs) integrated reports with the IR framework requirements. For this type of organization, in fact, legitimacy has a crucial relevance due to its mission of creating and delivering public value for society. This inevitably results in great pressure in terms of accountability. As a consequence, the search for legitimacy can result in an artificial and idealized representation of the activities carried out by an organization and their impacts, compromising the reliability of the report [28].

From a methodological point of view, previous studies in this research field usually applied text analysis, such as rhetorical analysis and discourse analysis [60]. Therefore, rhetorical analysis can represent a useful tool to better explore and understand some of the social consequences of discourse. 
In their pivotal work, [12] move from Aristotle and, incorporating aspects of persuasion from impression management and strategic communication studies, "elucidate (Aristotle's) key rhetorical elements of ethos, logos, and pathos".

According to the Authors:

(a) Ethos "refers to the persona, or projected character of a speaker/communicator, including their credibility and trustworthiness" and encapsulates elements such as similitude, ingratiation, deference, expertise, self-criticism, inclination to succeed, consistency. In the context of organizational reports, ethos reveals itself every time a speaker or a writer chooses and uses the pronouns "we", "you", and "I", with the aim of establishing an impression of cohesion, harmony and community [63].

(b) Logos "refers to the clarity and integrity of the argument", where persuasive techniques are argumentation, logic, warrants/justifications, claims, data evidence, and examples (e.g., historical). It is important to stress that, in the field of rhetoric, logos is not just "rationality" but the broader "appearance of rationality", more like "common sense".

(c) Pathos "refers to the audience's feelings and relies for persuasive effect on triggering audience emotions such as happiness, sadness, satisfaction, pity, or fear", expressed in terms of metaphors and identification mechanisms, which are often influenced by cultural and institutional dimensions [64].

These three elements reveal the characteristics of a good argument, identifying the dimensions of the persuasive appeal [37].

In their extensive and extremely articulated work, [7] locate the work of Higgins and Walker as the landmark when assessing the role of rhetoric in the domain of accounting and accountability, especially when it comes to the assumption that "the purpose of corporate narrative reporting and communication is to achieve specific communicative or political goals, such as convincing financial stakeholders of the financial soundness or creditworthiness of the company, persuading organizational audiences of the company's environmental credentials as in Higgins and Walker."

Several studies have tried to apply the above-mentioned models to conduct empirical investigations. More recently, [65] analyzed the use of language in communicating climate change information in Malaysia. They combined [66] impression management framework and the Aristotelian framework of [12]. Seven impression management strategies were identified: syntactical manipulation, rhetorical manipulation with the three dimensions of ethos, pathos and logos, attribution of organizational outcomes, thematic manipulation, selectivity, presence of visuals, graphs, highlighted words, bulleted points and performance comparison. Their findings confirmed the rhetorical nature of most of the information provided by the companies and this supported their attempt to gain legitimacy and manage impressions.

However, the use of rhetoric still represents an underdeveloped topic, in particular in the accounting field of research [67-69]. This statement becomes even more true if we consider the specific case of corporate disclosure on the impacts of a pandemic crisis.

\subsection{Critical Discourse Analysis (CDA)}

The use of the methodology called Critical Discourse Analysis (CDA) began in the 1980s. It aims to determine how language contributes to enhance and sustain dominant ideologies. As defined by [70], "Critical discourse analysis (CDA) is a discourse analytical research that primarily studies the way social power abuse and inequality are enacted, reproduced, legitimated and resisted by text and talk in the social and political context". It "explores the relationship between discourse and social reality" [71].

In CDA, the term ideology refers to the wider meaning of "world view" and it constitutes an element that can influence our processes of cognition and evaluation. The exercise of control involves the content as well as the structures of text and talk [70]. Fairclough [72] stated that the focus of CDA is on the linguistic elements to explain "their 
generally hidden determinants in the system of social relationships, as well as hidden effects they may have upon that system".

As a consequence, CDA analyzes the linguistic (lexical, grammatical or structural) elements of a text and defines their contribution to the persuasive effect that the author wants to achieve.

A "discourse" is "a particular way of talking and understanding the world" created by the use of language [73]. It may be determined by social structures, but can also have an impact on them [74]. Thus, CDA provides an intersection between social structure and language through the study of discourse production [75]. More in detail, CDA refers to the term "discourse" in two different ways: the first interpretation considers "discourse" as a mass noun about the linguistic elements of social life, such as the use of language in speech and writing [76]; the second one defines a "discourse" as a count noun or a specific way of describing a particular aspect of social life, for example, different discourses on climate change [77]. In this second case, a discourse can be different based on the period and/or country, topic and/or producers.

Considering its main features (notions of power and ideology, orientation towards change, emphasis on contextuality, micro- and macro-level analyses and interdisciplinarity), CDA can easily be applied in the field of critical accounting research [77]. It allows accounting researchers to analyze corporate narrative documents in a systematic and detailed way following a linguistic perspective [78]. It is a form of social research focused on language and its interconnection with elements of social life [79], as the socioeconomic context in which the text is produced.

There are several approaches within CDA [75] that are different in terms of their level of social aggregation (agency versus structure) and linguistic depth (broad versus detailed linguistic operationalization).

Theoretically, CDA is based on Halliday's systemic-functional grammar, in which there are three social functions realized by language: the "ideational" function, concerning the world around and inside us; the "interpersonal" function, about social interactions and relations; the "textual" function, on the relationship between representation and interaction to form a meaningful whole [80].

Reference [81] studied the relationship between language and society by developing a framework with three levels of analysis:

(a) The text (micro-level);

(b) The context of producing, distributing, receiving and adapting texts within a discourse community (meso-level);

(c) The dynamic socioeconomic context in which the discourse community can be located (macro-level).

The focus of the micro-level is on the linguistic features relevant to the text under investigation. They depend on the research objective, the genre of the text, the audience and the discourses it incorporates (i.e., finance, accounting, etc.). The meso-level aims to explain the reasons for the representation strategies in the text through the discourse practice context that comprises the production, distribution, reception and adaptation of texts. It focuses on the roles of members of a discourse community and their mutual relationships (i.e., the relationship between managers and shareholders and/or other stakeholders).

Finally, the macro-level takes into account the social formation (for example, the roles allocated to people) and its changes. It interprets the findings of text analysis in order to explain the representation of social actors.

This model was then extended by $[72,82]$ to include the interaction with semiosis (the formation of the meaning).

For our case study analysis, we followed the model of [77] that adopted an agencyfocused detailed linguistic analysis approach based on [79,83] Dialectical-Relational Approach, which, in turn, is based on Systemic Functional Linguistics [84]. Their analysis focused on the way social actors, entities, and social events are represented and evaluated 
and "whether actions are represented in ways which specify or conversely elide the agency of actors, and what the social and political significance of this textual 'choice' may be" [79].

\section{Sample, Data Collection, Method, Data and Analysis}

Our sample is composed of all the non-financial companies listed on the Milan Stock Exchange plus the 20 most important companies operating in the banking and insurance sector, and therefore includes-as of the end of July 2020-190 companies, grouped as follows by the industry sector (see Table 1).

Table 1. The sample.

\begin{tabular}{cc}
\hline Sector & No. \\
\hline Bank and insurance & 20 \\
Oil and gas & 5 \\
Chemicals & 5 \\
Manufacturing & 52 \\
Consumer goods & 42 \\
Health & 7 \\
Consumer services & 25 \\
Telecommunications & 4 \\
Public services & 14 \\
Technology & 16 \\
Total & 190 \\
\hline
\end{tabular}

Then, we excluded 65 companies for which the minutes of approval were not yet available or did not contain any information about COVID-19: thus, the final sample includes 125 companies, which constitute the starting point of the following analyses.

We decided to consider different sectors because not all of them are expected to suffer the same impacts of the pandemic crisis. For example, on the one hand, the pharmaceutical sector could benefit from this situation, due to the increase in pharmaceutical expenses all over the world; and a similar situation could concern the digital sector of the "new economy", characterized by an increase in customer numbers. On the other hand, the tourist and consumer goods sectors could be exposed to a negative exogenous shock. For this reason, our analysis aims to explore the presence of sectorial differences that follow the spread of COVID-19.

We extracted from these companies, directly from their websites or from the Italian Stock Exchange, the minutes of approval of the financial statements of their last available financial statements (as of 31 December 2019); pre-assembly info has been included only as long as it was included in the pdf file of the minutes.

We decided to consider this type of document for its accessibility and because it should contain a description of how the organization is addressing the pandemic crisis.

\subsection{Methodology}

As a method of research, we performed a manual content analysis [83]-as suggested by social science theory [84]-focusing on topics, quantity, and the quality of the information provided: this type of content analysis allowed us to overcome limitations of computer software. As suggested by other social science studies [85], to define the coding framework, we have referred to the already well-established models of rhetoric and critical discourse analysis [12,77]. The procedure of content analysis has been carried on via a manual approach, since the topics to be measured and evaluated contain a great amount of subjectivity and an emotional pattern and, as such, we reckon that the software was less equipped for catching the explicit (and implicit) meanings of the sentences. In detail, we preliminarily have assigned some companies' minutes to two members of our research teams, who performed the manual content analysis autonomously and later checked potential differences amongst their analysis. We chose as the counting factor for content analysis the sentences. 
Then, to assess the quality level of the disclosure, we considered only three items (future outlook, employees, and pandemic expenditure) that alone covers almost the total of the companies' disclosure. Following [86], we assessed the quality of each of the three items with a three levels scale with the value of 0 in case of absence of disclosure, the value of 1 for qualitative information and 2 for quantitative information. The maximum value a company could reach in terms of disclosure quality is equal to 6 .

\subsection{Analytical Framework}

The analysis of the response to the pandemic, as contained within the minutes of approval of the 2019 financial reports of Italian listed companies, was conducted through a dual theoretical model of analysis: rhetoric and critical discourse analysis (Figure 1).

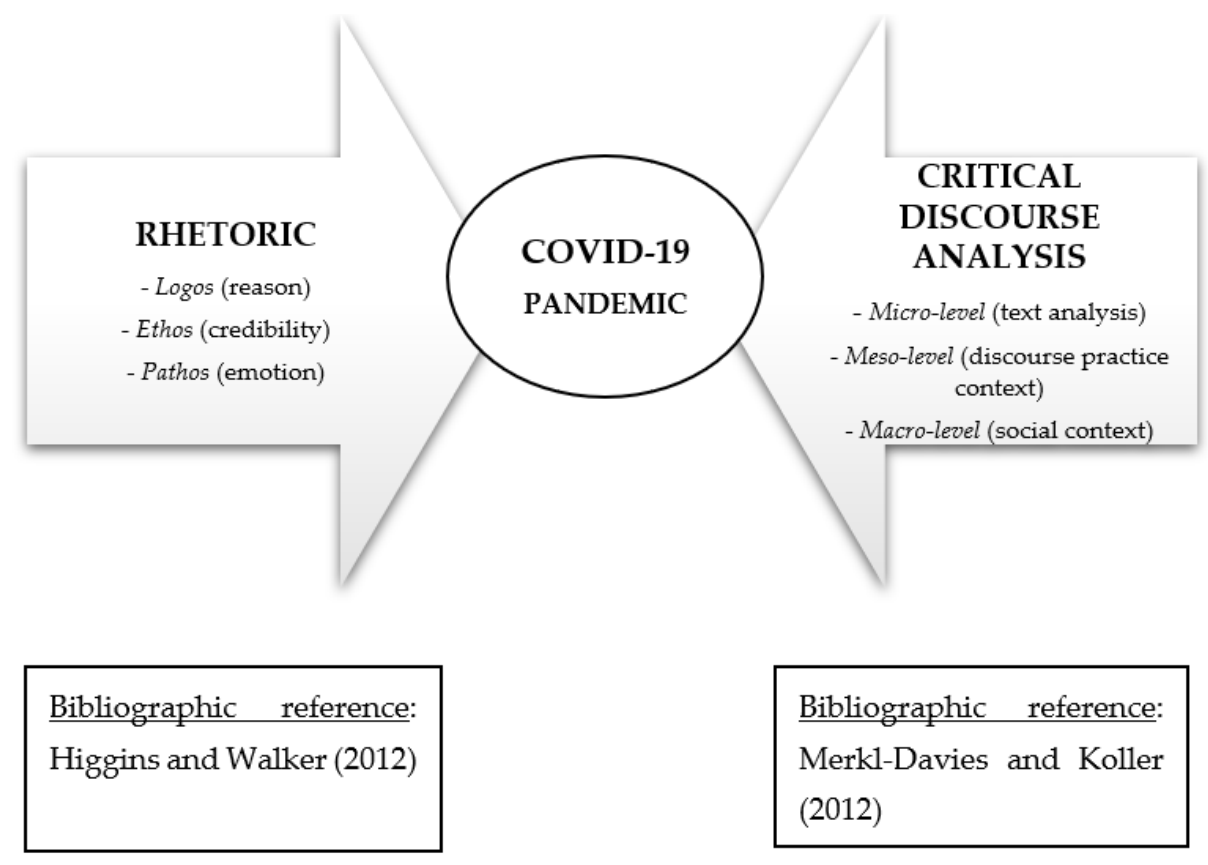

Figure 1. The Analytical Framework.

With the first instrument, it was possible to record the techniques adopted within the communication models, with particular reference to the emphasis given to emotional and not purely rational issues.

With critical discourse analysis, on the other hand, applied to a particularly significant case study (Brunello Cucinelli), it was made clear how the corporate communication of the pandemic phenomenon took place by making a pre-eminent appeal to metaphors, adjectivalism, and personification by the President of the tragedy in action.

The use of the tools proposed below is certainly not particularly new within accounting disciplines, although, we are convinced that the ideas that emerge from our work allow us to explore a new field of research, with very original and attractive results, while using a theoretical and conceptual framework that is already well established.

In fact, rhetoric and critical discourse analysis are the usual elements of textual analysis through which legitimation strategies are contextualized, particularly with regard to studies of corporate social responsibility (among others, [84]); in these contexts, importance and emphasis are given to the impersonality of speeches, to the use of repetition, to appeals to economic rationality.

The result is different in the pandemic: the picture that emerges, in fact, is that of an attempt, on the part of corporate communication, to appeal to paradigms of very high subjectivity (metaphors, important qualifying adjectives) in a context in which the 
entrepreneur, true pater familias, takes and guides the company, aiming it towards safer ports. The seafaring metaphor, in fact, is often present.

As such, the dramatic moment of the pandemic has been narrated with very particular linguistic techniques and methods.

Rather than proposing a new conceptual framework, therefore, the analyses we have carried out allow us to state that, by using the well-functioning models of rhetoric and critical discourse analysis, corporate communication has been able, in a protean and fluid effort, to adapt to a more subjective form of communication, which appeals more to the emotional and sentimental sides than to the strictly rational ones.

\subsection{Rhetorical Analysis}

The minutes were considered, with specific reference to the description of the pandemic and its consequences, using the means of linguistic analysis and rhetoric suggested by [12].

It is, therefore, the choice of rhetoric that motivates and gives significance to the decision to examine the minutes of the meeting only: in fact, these documents reveal, in general, a less technical dimension than financial reports and as such, they appear to be better suited to be the objects of discussion.

We chose as the counting factor for content analysis all the sentences, rubricating each of them according to one (or more) of the features proposed by [12].

For instance, the following sentences, respectively named as ethos, logos and pathos, are examples.

a. Ethos: "We have always maintained, and we are still confident, that our strategic positioning is united to the high level of internationalization, continuous updating in the field of technology and to the offer of always innovative products, and will allow us to counteract this difficult time finding ourselves prepared to seize the opportunities arising from the desirable resolution of this global emergency".

b. Logos: "The measures adopted to contain the spread of the virus and the effects of the health emergency condition the Group's production activities, the progress of programs, the supply chain and the possibility for customers to withdraw products and systems. To this must be added the effects that the crisis will have on demand in the markets in which the Group operates, and in particular in the civil aeronautical sector".

c. Pathos: "The personal concern aroused by the news and messages received by the Chinese partners turned into 'pain' when the health emergency situation was discussed with employees during a meeting held in company".

This led us to select 746 sentences. As a preliminary, we contextualized them according to three different dimensions: the locus of the information, the speaker, the type of information.

Results are shown in Tables $2-4$ below.

Table 2. The locus of the information.

\begin{tabular}{cc}
\hline Locus & $\%$ \\
\hline Minutes of approval & $48 \%$ \\
Pre-assembly information & $41 \%$ \\
Chairman's Salutation & $11 \%$ \\
Total & $100 \%$ \\
\hline
\end{tabular}


Table 3. The speaker.

\begin{tabular}{cc}
\hline Speaker & $\%$ \\
\hline Chairman & $43 \%$ \\
Shareholder & $14 \%$ \\
CEO & $13 \%$ \\
Executives & $12 \%$ \\
Other & $18 \%$ \\
Total & $100 \%$ \\
\hline
\end{tabular}

Table 4. The type of information.

\begin{tabular}{cc}
\hline Type & $\%$ \\
\hline Qualitative & $91 \%$ \\
Quantitative & $9 \%$ \\
Total & $100 \%$ \\
\hline
\end{tabular}

Put together, the three tables describe a context almost exclusively constituted by qualitative information, most of it provided by the Chairman and/or the Chief Executive Officer, while quite interestingly the locus of the information is placed, in more than $40 \%$ of cases, in the pre-assembly meeting.

The content of the sentences has been categorized, in line with some previous studies, as in Table 5, which follows.

Table 5. The content of information.

\begin{tabular}{cc}
\hline Type & $\%$ \\
\hline Future outlook & $56 \%$ \\
Employees & $18 \%$ \\
Pandemic expenditures & $8 \%$ \\
Liquidity & $4 \%$ \\
Risks & $4 \%$ \\
Revenues & $3 \%$ \\
Profit and loss & $2 \%$ \\
EBITDA & $1 \%$ \\
Debt & $1 \%$ \\
Supply chain & $1 \%$ \\
Litigation & $1 \%$ \\
Remuneration & $1 \%$ \\
Stock Exchange time trend & $1 \%$ \\
Total & $100 \%$ \\
\hline
\end{tabular}

Hence, more than half of the information (56\%) is placed within the realm of future perspectives and 15\% refers to quantitative data and items, from liquidity to debt; interestingly, 26\% overall is devoted to the employees and the charitable activities of the company (the remaining $3 \%$ being related to minor topics).

The figure of $26 \%$ is particularly noteworthy, as it is closely bound up with the effects of the pandemic in terms, first of all, of protecting the health and integrity of employees and, secondly, of the company's ethical commitment.

The considerations that precede provide the background, moreover, to the exploration, by means of rhetoric, of the contents as shown in Table 5; Table 6 summarizes the results. 
Table 6. Rhetoric and COVID-19 content.

\begin{tabular}{cc}
\hline Approach & $\%$ \\
\hline Logos & $68 \%$ \\
Pathos & $12 \%$ \\
Ethos & $11 \%$ \\
Ethos/Logos & $6 \%$ \\
Ethos/Pathos & $1 \%$ \\
Logos/Pathos & $1 \%$ \\
All & $1 \%$ \\
Total & $100 \%$ \\
\hline
\end{tabular}

The main result of Table 6 is the relevance of sentences written for logos, which constitutes the majority but with a relatively low percentage $(68 \%)$. In other words, a small but consistent part of the information and sentences call for features of not exclusive rationality such as empathy and human interaction (pathos) as well as self-affirmation and trustworthiness (ethos).

Furthermore, the emphasis on emotionality within these arguments, seems to be an even more fascinating theme, since it is completely detached, in general, from the corporate and rational logic of economic-financial communication.

Below are some interesting sentences extracted, all with a strong component of emotional value.

Aeffe (Consumer goods)

"But above all, we have already prepared ourselves from the 3rd to start again in sanitized environments with masks, sanitizing gel, gloves, thermoscanner, lists of people in smart working!"

Webuild (Manufacturing)

"The Group has promoted various initiatives to support communities facing the emergency, with interventions coordinated with the competent authorities; in particular, a donation has been made for an amount equal to Euro 30,000, to the Community of Sant'Egidio to support the welfare activities of families and individuals in difficulty related to Coronavirus and, in addition, 130,500 Ffp2 masks have been donated to hospitals engaged on the front line in the fight against coronavirus, nursing homes for the elderly (RSAs), hospitals, the Police and the Municipality of Valfornace (Macerata), to which the Group had already donated a school following the earthquake of 2017".

Webuild (Manufacturing)

"The Company does not exclude, for the future, further interventions to demonstrate its solidarity and closeness to the realities most affected by the state of emergency in progress".

Brunello Cucinelli (Consumer goods)

"However, remarked the President, a video message 'of great humanity' precisely from the Chinese partners was 'a source of great hope for the resumption of work' that he wanted to share with employees, collaborators and other 'friends in the world' with a letter dated March 17th, in conjunction with the advent of spring when swallows migrate".

Hera (Consumer services)

"A special thanks to all the staff for their sense of responsibility in reacting promptly to the necessary organizational changes and the difficulties imposed by the current emergency, ensuring full continuity on all our services of primary utility that are particularly strategic for the country, especially at this time."

Mediaset (Consumer services)

"The pandemic hit hard, but the dreams of a great Italian company do not stop".

Telecom (Telecommunications)

"The health crisis triggered by the spread of the coronavirus involves us all and touches us all closely".

A potential explanation of the significance (in terms of weight and emphasis) of the emotional and not exclusively rational dimension may be that, in the dramatic situation 
provoked by COVID-19, companies leverage on and advocate emotional and sentimental matters so as to arouse, through the instrument of rhetoric, a profound effect of support and solidarity.

Moving forward in the investigation of emotional factors, it is worth focusing attention on sector-by-sector segregation. Table 7 provides some interesting insights in order to delve further into the topic.

Table 7. Data breakdown per rhetoric means.

\begin{tabular}{|c|c|c|c|c|c|c|c|c|c|}
\hline Industries & $\begin{array}{c}\% \\
\text { Sample }\end{array}$ & $\%$ Sent & Pathos & Logos & Ethos & Pat/Log & All & Log/Eth & Pat/Eth \\
\hline Bank and insurance & $11 \%$ & $3 \%$ & $8 \%$ & $4 \%$ & $0 \%$ & $0 \%$ & $0 \%$ & $0 \%$ & $0 \%$ \\
\hline Oil and gas & $3 \%$ & $0 \%$ & $0 \%$ & $0 \%$ & $0 \%$ & $0 \%$ & $0 \%$ & $0 \%$ & $0 \%$ \\
\hline Chemicals & $3 \%$ & $1 \%$ & $0 \%$ & $1 \%$ & $0 \%$ & $0 \%$ & $0 \%$ & $0 \%$ & $0 \%$ \\
\hline Manufacturing & $27 \%$ & $29 \%$ & $31 \%$ & $32 \%$ & $27 \%$ & $33 \%$ & $13 \%$ & $0 \%$ & $33 \%$ \\
\hline Consumer goods & $22 \%$ & $29 \%$ & $26 \%$ & $27 \%$ & $48 \%$ & $22 \%$ & $88 \%$ & $11 \%$ & $67 \%$ \\
\hline Health & $4 \%$ & $1 \%$ & $0 \%$ & $2 \%$ & $0 \%$ & $0 \%$ & $0 \%$ & $0 \%$ & $0 \%$ \\
\hline Consumer services & $13 \%$ & $22 \%$ & $26 \%$ & $23 \%$ & $20 \%$ & $11 \%$ & $0 \%$ & $18 \%$ & $0 \%$ \\
\hline Telecommunications & $2 \%$ & $1 \%$ & $2 \%$ & $1 \%$ & $0 \%$ & $0 \%$ & $0 \%$ & $0 \%$ & $0 \%$ \\
\hline Public services & $7 \%$ & $10 \%$ & $7 \%$ & $8 \%$ & $5 \%$ & $33 \%$ & $0 \%$ & $50 \%$ & $0 \%$ \\
\hline \multirow[t]{2}{*}{ Technology } & $8 \%$ & $2 \%$ & $0 \%$ & $2 \%$ & $0 \%$ & $0 \%$ & $0 \%$ & $20 \%$ & $0 \%$ \\
\hline & $100 \%$ & $100 \%$ & $100 \%$ & $100 \%$ & $100 \%$ & $100 \%$ & $100 \%$ & $100 \%$ & $100 \%$ \\
\hline
\end{tabular}

For example, the number of sentences is not directly related to the number of companies in the sample, since for instance, bank and insurance companies-which represent $11 \%$ of the sample-account for only $3 \%$ of the sentences; at the same time, other sectorsfor instance, consumer goods and services together-account for $35 \%$ of the sample but represent $52 \%$ of the overall sentences.

The results are in line with the rhetorical instrument and its objectives; in other words, the sectors that most exhibit contents of the description of the pandemic, and contents of empathy and sentimental collection through rhetoric as well, are, in fact, those with the most immediate involvement and interaction with consumers.

The association appears less marked and more nuanced, on the other hand, in the case of intermediate or primary sectors such as manufacturing.

Three other interesting points arise from the breakdown of sentences according to industry. First, pathos is rebus sic stantibus higher in the bank and insurance sector, as if the more robust sectors felt the need, even within a context of rather limited information, to reiterate emotional ties with the interlocutor.

Second, consumer goods companies appeal more strongly to their ethical commitment than other sectors. Third, companies operating in the technology field place less emphasis on the pandemic issue, which, when dealt with, tends to be debated on highly rational grounds.

Table 8 disentangles further data, dividing them according to the industry and the typespecific information and showing the quantity of the information provided by companies belonging to different sectors. 
Table 8. Data breakdown per type-specific information.

\begin{tabular}{|c|c|c|c|c|c|c|c|c|}
\hline Industries & $\begin{array}{c}\% \\
\text { Sample }\end{array}$ & $\%$ Sent & $\begin{array}{c}\text { Future } \\
\text { Outlook }\end{array}$ & Financials & Employees & Risks & $\begin{array}{c}\text { Pandemic } \\
\text { Expenditure }\end{array}$ & Other \\
\hline Bank and insurance & $11 \%$ & $3 \%$ & $2 \%$ & $11 \%$ & $0 \%$ & $0 \%$ & $9 \%$ & $7 \%$ \\
\hline Oil and gas & $3 \%$ & $0 \%$ & $0 \%$ & $0 \%$ & $0 \%$ & $0 \%$ & $0 \%$ & $0 \%$ \\
\hline Chemicals & $3 \%$ & $1 \%$ & $1 \%$ & $0 \%$ & $0 \%$ & $0 \%$ & $0 \%$ & $0 \%$ \\
\hline Manufacturing & $27 \%$ & $29 \%$ & $32 \%$ & $19 \%$ & $23 \%$ & $56 \%$ & $23 \%$ & $22 \%$ \\
\hline Consumer goods & $22 \%$ & $29 \%$ & $28 \%$ & $34 \%$ & $38 \%$ & $19 \%$ & $11 \%$ & $41 \%$ \\
\hline Health & $4 \%$ & $1 \%$ & $1 \%$ & $1 \%$ & $0 \%$ & $0 \%$ & $0 \%$ & $4 \%$ \\
\hline Consumer services & $13 \%$ & $22 \%$ & $25 \%$ & $28 \%$ & $20 \%$ & $19 \%$ & $9 \%$ & $11 \%$ \\
\hline Telecommunications & $2 \%$ & $1 \%$ & $1 \%$ & $1 \%$ & $1 \%$ & $3 \%$ & $2 \%$ & $0 \%$ \\
\hline Public services & $7 \%$ & $10 \%$ & $7 \%$ & $6 \%$ & $17 \%$ & $3 \%$ & $28 \%$ & $15 \%$ \\
\hline \multirow[t]{2}{*}{ Technology } & $8 \%$ & $2 \%$ & $1 \%$ & $0 \%$ & $1 \%$ & $0 \%$ & $19 \%$ & $0 \%$ \\
\hline & $100 \%$ & $100 \%$ & $100 \%$ & $100 \%$ & $100 \%$ & $100 \%$ & $100 \%$ & $100 \%$ \\
\hline
\end{tabular}

Among the points of major interest of the results in Table 8 show, first, that future outlook is treated in a similar pattern within the sample, with no particular differences depending on the sector. On the contrary, and this is not unexpected, data of an economicfinancial nature come up more frequently in the banking and insurance industry. Of particular interest is also the subject of employees, which, although salient, is completely neglected by many sectors, whereas it is discussed intensely by sectors close to the consumer and the public sector. The issue of risks, on the other hand, is overrepresented in manufacturing, less in other sectors. The disaggregation of the specific topics of discussion, according to the different sectors, supports the strong relationship between the pandemic issue, the nature of the sectors themselves and the type of information provided.

Finally, the last analysis concerns the identification of the quality level of the information provided by companies.

We decided to concentrate our attention only on three items (future outlook, employees and pandemic expenditure) because alone they represent almost the total of the companies' disclosure. Then, as suggested by [86], we assessed the quality of each of the three items by using a three-level scale: in particular, we assigned the value of 0 in case of absence of disclosure, the value of 1 for qualitative information and 2 for quantitative information. Consequently, the maximum value in terms of disclosure quality that a company could reach is equal to 6 .

The mean of the quality score for the whole sample is equal to 1.58 (out of 6 points): this result reveals a low level of the disclosure quality and the presence mainly of qualitative information. It is also interesting to notice that none of the companies reaches the maximum value of six (in other words, 2 points for each of the 3 items considered). If we compare the mean score of the whole sample (1.58) with the mean score of each sector, it is possible to observe how six sectors are below the average and two of them in particular (bank and insurance, health) show a much lower value (respectively, 0.92 and 0.83), while the remaining four are above the mean. Not surprisingly, these sectors are those close to the consumer and the public sector, thus confirming the previous analysis.

After a preliminary exam of our data, we decided to use the Fisher exact test to verify the presence of an association between sectors and quality score. For computational reasons, we had to transform the variable score to a dichotomous one by coding as " 0 " all scores from 0 to 3 and as " 1 " all results from 4 to 6 .

The result of the Fisher test is reported in Table 9. 
Table 9. Fisher test.

\begin{tabular}{|c|c|c|c|c|c|c|c|c|c|c|c|}
\hline Score * & $\begin{array}{l}\text { Bank and } \\
\text { Insurance } \\
\text { (1) }\end{array}$ & $\begin{array}{l}\text { Oil and } \\
\text { Gas (2) }\end{array}$ & $\begin{array}{c}\text { Chemicals } \\
\text { (3) }\end{array}$ & $\underset{\text { (4) }}{\text { Manufacturing }}$ & $\begin{array}{l}\text { Consumer } \\
\text { Goods (5) }\end{array}$ & $\begin{array}{l}\text { Health } \\
\text { (6) }\end{array}$ & $\begin{array}{l}\text { Consumer } \\
\text { Services } \\
\text { (7) }\end{array}$ & $\underset{\text { (8) }}{\text { Telecommunications }}$ & $\begin{array}{l}\text { Public } \\
\text { Services } \\
\text { (9) }\end{array}$ & $\begin{array}{c}\text { Technology } \\
\text { (10) }\end{array}$ & Total \\
\hline 0 & 13 & 1 & 1 & 42 & 24 & 6 & 18 & 0 & 4 & 2 & 111 \\
\hline 1 & 0 & 0 & 0 & 4 & 3 & 0 & 1 & 1 & 4 & 1 & 14 \\
\hline Total & 13 & 1 & 1 & 46 & 27 & 6 & 19 & 1 & 8 & 3 & 125 \\
\hline
\end{tabular}

Fisher's exact $=0.015$. $*$ Scores from 0 to 3 are coded as " 0 ". Scores from 4 to 6 are coded as " 1 ".

The null hypothesis for the test is that there is no association between the rows and columns of the table. This means that the probability of a result being in a particular row is not influenced by being in a particular column. In our case, the null hypothesis is rejected at a $5 \%$. The test confirms there is an association between the sectors and the levels of disclosure quality coded as 0 (low quality) and 1 (high quality). Being a hypotheses test about the presence of an association, it gives no information about the size of the association and does not allow to make particular inferences about its effect.

\subsection{A Critical Discourse Analysis (CDA) of a Case Study}

In this section we have used some devices of Critical Discourse Analysis (in particular, those referred to in [77]) in relation to a specific case study (Brunello Cucinelli).

The motivation behind the choice of running a single case study lies in the need for a more in-depth and structured investigation of the dialectics used for the representation of the pandemic; in this sense, the technical means of critical discourse analysis, in particular its declination for the purposes of corporate reporting, seems suitable.

More in detail, we have made use of the framework in [77], which is built on three levels (micro-level, meso-level, and macro-level) to capture the interrelationship between text and context. Below some preparatory insights on the procedure we have followed.

\subsubsection{Micro-Level: Text}

Micro-level text analysis focuses on the specific linguistic features which are of particular importance for the text under investigation [77].

In line with [77], we center our attention on the following linguistic devices: referential vagueness, passivization, metaphors, adjectives.

Referential vagueness and passivization, broadly speaking, obfuscates social agency, thus representing processes in a more abstract, factual manner [77].

Metaphor is a device in which accountants create and disseminate meaning about the world, while adjectives help in building value statements regarding the desirability, importance, or usefulness of social actors, events, or ideas.

\subsubsection{Meso-Level: Discourse Practice Context}

Meso-level analysis explains the reasons for the representation strategies in the text by recourse to the discourse practice context, which includes the production, distribution, reception and possible adaptation of texts.

As in [76], "in the case of corporate narrative documents the focus of analysis is on the relationship between managers and shareholders, stakeholders, and intermediaries, such as financial analysts and the media".

\subsubsection{Macro-Level: Social Context}

Macro-level analysis involves taking the wider social formation into account to interpret the findings of the text analysis [77].

In this sense, our analysis will be built mainly on the explicit and implicit role of pandemic.

The case story: Brunello Cucinelli. As a case study, we have selected Brunello Cucinellia world leader in the field of luxury fashion (cashmere) — as the minutes of its shareholders' meeting include remarkable suggestions and ideas regarding linguistics in action in the field of corporate reporting. 
Brunello Cucinelli's Statement at the Shareholders' Meeting: Micro-level.

The statement of Brunello Cucinelli, owner and founder of the company, is placed at the end of the shareholders' meeting, five pages long and written in Italian only.

It includes six items of referential vagueness and passivization, eight metaphors and 31 adjectives.

Referential vagueness elements [partners (1) other companies (2) partners (3) European and American colleagues (4) contributors (5) multi-brand clients (6)] and passivization [the current pandemic has been tackled (1) it has been possible to move further (2) the help has been extended (3) some commitments have been requested (4) every relationship will be managed (5) chances can be obtained (6)] lead to some reflections.

In fact, in a statement that is well-structured and rich in linguistic devices, such as metaphors and the use of adjectives, referential vagueness is limited and most of the sentences are developed in the active and not passive verb; the data above shows that the President meant, on the contrary, to make more than minimal use of other linguistic techniques.

On the other hand, subjectification and the vitalistic approach are typical traits of Cucinelli's personality and, as such, are mirrored in a linguistic mechanism in which the vagueness of reasoning and impersonality give way, the former to clarity of thought and the latter to a clear progression of discourse, without concessions to impersonal verbs.

Metaphors and adjectives, in effect, were used profusely; the former as shown in the following:

(a) "I will be sending you a letter of spring when the swallows emigrate";

(b) "Man is a sailor like Ulysses";

(c) "Man is like Columbus waiting for mother earth";

(d) "We must be like Einstein and Leonardo";

(e) "We will be like Gengis Khan and in 2 days we will do what others do in 10";

(f) "In this sea, with different boats and different captains";

(g) "The pandemic is a hailstorm for humanity";

(h) "We are like Marcus Aurelius between the plagues and the war on the Germans".

The metaphors employed have a powerful historical and adventuresque content and are mainly connected to marine themes (sea, storms, Ulysses, Columbus, boats, captains); in a lesser tone, there are also references to great men of war of antiquity, such as Genghis Khan, and to the philosopher emperor Marcus Aurelius.

The climate that is aroused via those metaphors is therefore inspirational, of important goals and epochal challenges such as the pandemic.

Even more emblematic is the employment of adjectives, 31 in all, which paint a picture of strong emphasis and great communicative effectiveness. In detail they are: Valuable, Exciting, Important, Moral, Dramatic, Personal, Shared, Great, Great, Difficult, Great, New, Fundamental, More, Positive, Lovable, Special, Generous, Dramatic, Prone, Fundamental, Human, Right, Correct, Honorable, Fundamental, Human, Thinking, Beautiful, Healthy, Solid. Apart from the technique of repetition (dramatic, fundamental, great) the adjectives used are relatively rare in corporate communication and, in perfect continuity with the metaphors, echo an almost ancient grandeur and the call to a spirit of greatness and self-denial.

As for the referential vagueness and the passivization, which move together, metaphors and adjectives collaborate and mutually express a relationship of grandeur and might, of resistance to the pandemic through a new humanism.

Brunello Cucinelli's Statement at the Shareholders' Meeting: Meso-level

If it is true, as mentioned above, that in the case of corporate narrative documents, the focus of analysis is on the relationship between company and its shareholders, Brunello Cucinelli's statement tackles an even wider audience. The lexical, narrative and syntactic devices used, in fact, address such a wide audience that, perhaps, it embraces more the notion of a stakeholder than that of shareholders only. At the end of reading his speech, in fact, even a neutral and independent reader, not involved in economic relations with the company, is likely to experience feelings of closeness and commitment. 


\section{Macro-level: Social Context}

As anticipated above, the main social context for the macro-level is, of course, pandemic.

The analysis of the President's speech, via the instrument of critical discourse analysis, highlights as essential narrative elements the use of qualifying adjectives of considerable impact and the systematic presence of particularly striking metaphors, all in the prospect of a President who stands as a pater familias and who intends to guide the company into safer waters.

By doing so and by interpreting it in this way, critical discourse analysis appears to be extremely successful, in the dramatic case of the ongoing pandemic, not in outlining a rhetorical means of legitimacy but rather in emphasizing the personification and the taking charge, also emotional, by a President towards the community to which his company belongs.

\section{Conclusions, Limitations and Future Research}

The emergency related to the COVID-19 pandemic has been causing problems all over the world, not only from a medical point of view but also in terms of economic perspectives, with the spread of a general sense of economic uncertainty. In the specific case of Italy, the government decrees focused initially only on containing the health emergency. However, also as a consequence of the restrictions on freedom of movement, some negative impacts on companies' normal life emerged, such as the stop of production activity and the presence of a liquidity crisis. Consequently, the need to address these issues arose. Following the spread of COVID-19, the interest of academics and practitioners started to focus on some other topics connected to such a pandemic, also from the perspective of the social sciences, such as accounting and accountability and social sustainability. The purpose of our paper is to study the use and the extent of companies' accounting communication during the pandemic to depict a positive image of themselves with their stakeholders and/or repair it, thus considering not only the text but also contexts within which the text is produced.

We extracted all the companies listed on the Milan Stock Exchange and, by applying the model by [12], we selected and assessed all the sentences devoted to the issue of COVID-19 used in the shareholders' meeting as the counting factor of content analysis, and explored them via rhetoric.

The main results of our preliminary study confirm a high degree of awareness of the pandemic and a strong use of non-rational, emotional content, with particular reference to the sectors most exposed to direct customer relations (e.g., consumer goods and services). This could mean that the dramatic context of the COVID-19 diffusion has pushed companies to appeal to rhetorical instruments to construct a sense of commonality with their stakeholders and to obtain more support and solidarity from them. Moreover, we observed that the type of information is almost exclusively qualitative, provided by the Chairman and/or the Chief Executive Officer, and more than $40 \%$ placed in the pre-assembly meeting. Moreover, $56 \%$ of the information refers to future perspectives, $15 \%$ is made up of quantitative data and items, such as liquidity, and $26 \%$ concerns the topics of employees and charitable activities undertaken by the company.

We did not observe differences between sectors on the disclosure of the item "future outlook", while economic and financial information are more commonly provided by the bank and insurance industry; information on employees is typical of consumer-sensitive sectors and the issue of risks is more threatened in manufacturing. Concerning the topic of quality of the disclosure, we observed, in general, a low level of disclosure, with sectors close to the consumers and the public sector as the best performers.

Furthermore, we have tested critical discourse analysis with a case study. While in general, CDA is used by researchers to shed light on legitimacy tactics by the preparers of corporate communication $[63,64]$, in the dramatic current wave of the pandemic, it draws attention to personification and taking charge, also emotional, by the President of the company towards the community to which his company belongs. 
Of course, these results must be interpreted in relation to the sample examined, the nature of the study conducted, and the scope of the analysis itself: the minutes of the Shareholders' Meeting. These elements represent, at the same time, the limitations of the work and the areas of possible future development of the research. Another limit concerns the subjectivity of the analysis that is mainly based on the qualitative impressions of the researchers [87-94]. In addition, it should be borne in mind that the companies that have reported better results in terms of quantity and quality of disclosure are not necessarily the companies that pay more attention to the COVID-19 problem. Even referring in general to the literature on sustainability, it is not possible to say that companies that claim to act in a sustainable way are actually so or are more sustainable than other companies that do not declare it. Another limitation of our manuscript lies in the instrument itself of content analysis: according to some authors [95], for instance, it is advisable to test the validity of the hypotheses via post facto research, namely making use of different (and subsequent) forms of test. This limitation, at the very same time, could foster new avenues of research, for instance, validating our hypothesis via an analysis of another set of corporate communication (website, social, and so on). In this sense, our work, although in our opinion contains some points of originality, also contains limitations that shape it, in fact, as a first preliminary step of research, important but to be confirmed with future rigorous investigations.

The contributions of the study from a theoretical point of view are twofold. First, it has theoretical relevance due to the fact that it represents one of the first pieces of research that studies the role of accounting communication during the peculiar context of a pandemic crisis, such as that of COVID-19. The current pandemic crisis has many peculiarities compared to other crises both in terms of severity and impact [3] and it is affecting the whole of society. Second, it confirms the importance of rhetorical analysis in understanding the quality and the meaning of the information provided by the companies.

Referring to the practical implications, our findings provide useful suggestions to organizations about crisis communication. First, in communicating about the crisis, organizations preferred to adopt emotional content to create an empathic relation with their stakeholders and to obtain their support. Moreover, the focus of the communication, commonly shared by all the sectors, is not on past results, but on future perspectives, for constructing a common climate of "hope" for the future. Second, organizations could benefit from the results of this study by gaining awareness about the current low quality of the disclosure provided about the crisis, which allows for great margins for improvement. The results of the analysis can help in identifying the main points of weakness of their communication and refine them in the future. In fact, improving the quality of their communication can help in obtaining greater support from their stakeholders during a crisis. Amongst the practical implications for policymakers, we believe that shedding light on the rhetoric mechanisms could help regulators and policymakers to develop accounting and sustainability standards more and more able to catch the overall complexity of corporate communication, also concerning the impacts of a pandemic crisis. Finally, this study could be inspirational in understanding the importance of the creation of a new workforce specialized in managing the crisis [8]. The reading of the minutes demonstrated the relevance of quickly confronting the pandemic in the right way. For this reason, it could be useful for organizations to become more prepared to confront a similar context in the future.

Important work remains to be done on the role of rhetoric in the presence of a pandemic crisis. Below we provide some suggestions for further investigations.

Attractive avenues of investigation could be devoted to more informal corporate communication (social, website) through linguistic analysis conducted with more advanced and automatic tools, including the use of software and artificial intelligence. Additionally, empirical research should also consider more than just one country and more than one year for the analysis. Considering the specific case of COVID-19 diffusion, it could be that the major impacts of the pandemic crisis will be visible only in the next few years, and, for this reason, there could be changes in the amount and type of information disclosed by the 
company in the future. For this reason, future research should examine this research topic during the evolving situation.

Author Contributions: Conceptualization, L.G., V.M., P.T. and M.C.; construction of the database and data analysis, L.G., V.M., P.T. and M.C.; writing the paper L.G. and V.M. All authors have read and agreed to the published version of the manuscript.

Funding: This research received no external funding.

Institutional Review Board Statement: Not applicable.

Informed Consent Statement: Not applicable.

Data Availability Statement: The data presented in this study are available on request from the corresponding author.

Acknowledgments: The authors acknowledge Libero Istituto Universitario C.Cattaneo (LIUC) for the financial support given to their research project.

Conflicts of Interest: The authors declare no conflict of interest.

\section{References}

1. Baker, S.R.; Bloom, N.; Davis, S.J.; Terry, S.J. COVID-Induced Economic Uncertainty; NBER Working Paper No. 26983; National Bureau of Economic Research: Cambridge, MA, USA, 2020.

2. OECD. The Territorial Impact of COVID-19: Managing the Crisis across Levels of Government. Available online: http: / / www.oecd.org/coronavirus / policy-responses / the-territorial-impact-of-covid-19-managing-the-crisis-across-levelsof-government-d3e314e1/2020 (accessed on 1 December 2020).

3. Baum, T.; Mooney, S.K.; Robinson, R.N.; Solnet, D. COVID-19's impact on the hospitality workforce-new crisis or amplification of the norm? Int. J. Contemp. Hosp. Manag. 2020, 32, 2813-2829. [CrossRef]

4. Eizenberg, E.; Jabareen, Y. Social sustainability: A new conceptual framework. Sustainability 2017, 9, 68. [CrossRef]

5. Buhr, N. Corporate silence: Environmental disclosure and the North American Free Trade Agreement. Crit. Perspect. Account. 2001, 12, 405-421. [CrossRef]

6. Matsumoto, D.; Pronk, M.; Roelofsen, E. What makes conference calls useful? The information content of managers' presentations and analysts' discussion sessions. Account. Rev. 2011, 86, 1383-1414. [CrossRef]

7. Merkl-Davies, D.M.; Brennan, N.M. A theoretical framework of external accounting communication. Account. Audit. Account. J. 2017, 30, 433-469. [CrossRef]

8. Im, J.; Kim, H.; Miao, L. CEO letters: Hospitality corporate narratives during the COVID-19 pandemic. Int. J. Hosp. Manag. 2020, 92, 569.

9. Pupovac, S.; Moeman, L. Hybrid accounts: Shell's letter to Mr. and Mrs. shareholder. Account. Audit. Account. J. 2017, 30, 1184-1201. [CrossRef]

10. Gray, R.H.; Bebbington, J.; Gray, S. Social and Environmental Accounting Developing the Field; Sage: London, UK, 2010; Volume II.

11. Lupu, I.; Sandu, R. Intertextuality in corporate narratives: A discursive analysis of a contested privatization. Account. Audit. Account. J. 2017, 30, 534-564. [CrossRef]

12. Higgins, C.; Walker, R. Ethos, logos, pathos: Strategies of persuasion in social/environmental reports. Account. Forum. 2012, 36, 194-208. [CrossRef]

13. Dobers, P.; Springett, D. Corporate social responsibility: Discourse, narratives and communication. Corp. Soc. Responsib. Environ. Manag. 2010, 17, 63-69. [CrossRef]

14. Wang, V.X.; Xing, B.B. Battling Uncertainty: Corporate Disclosures of COVID-19 in Earnings Conference Calls and Annual Reports. Available online: https:/ /ssrn.com/abstract=3586085 (accessed on 28 April 2020).

15. García-Sánchez, I.M.; Raimo, N.; Marrone, A.; Vitolla, F. How does integrated reporting change in light of COVID-19? A Revisiting of the content of the integrated reports. Sustainability 2020, 12, 7605. [CrossRef]

16. Jayasinghe, K.; Uddin, S. Continuity and change in development discourses and the rhetoric role of accounting. J. Account. Emerg. Econ. 2019, 9, 314-334. [CrossRef]

17. Gray, R.H.; Bebbington, J.; Walters, D. Accounting for the Environment; Paul Chapman: London, UK, 1993.

18. Amernic, J.H.; Russell, J.C. Guidelines for CEO-speak: Editing the language of corporate leadership. Strategy Leadersh. 2007, 35, 25-31. [CrossRef]

19. Brennan, N.M.; Merkl-Davies, D.M. Rhetoric and argument in social and environmental reporting: The dirty laundry case. Account. Audit. Account. J. 2014, 27, 602-633. [CrossRef]

20. Amernic, J.H.; Craig, R.J. 9/11 in the service of corporate rhetoric: Southwest Airlines' 2001 letter to shareholders. J. Commun. Inq. 2004, 28, 325-341. [CrossRef]

21. Greiner, M.; Kim, J. Corporate political activity and greenwashing: Can CPA clarify which firm communications on social \& environmental events are genuine? Corp. Soc. Responsib. Environ. Manag. 2021, 28, 1-10. 
22. Chamorro, A.; Bañegil, T.A. Green marketing philosophy: A study of Spanish firms with ecolabels. Corp. Soc. Responsib. Environ. Manag. 2006, 13, 11-24. [CrossRef]

23. Baughn, C.C.; Bodie, N.L.; McIntosh, J.C. Corporate social and environmental responsibility in Asian countries and other geographical regions. Corp. Soc. Responsib. Environ. Manag. 2007, 14, 189-205. [CrossRef]

24. Welford, R.; Chan, C.; Man, M. Priorities for corporate social responsibility: A survey of businesses and their stakeholders. Corp. Soc. Responsib. Environ. Manag. 2007, 15, 52-62. [CrossRef]

25. Song, B.; Wen, J. Online corporate social responsibility communication strategies and stakeholder engagements: A comparison of controversial versus noncontroversial industries. Corp. Soc. Responsib. Environ. Manag. 2020, 27, 881-896. [CrossRef]

26. Garcia-Torea, N.; Fernandez-Feijoo, B.; De La Cuesta, M. CSR reporting communication: Defective reporting models or misapplication? Corp. Soc. Responsib. Environ. Manag. 2020, 27, 952-968. [CrossRef]

27. García-Sánchez, I.M.; Araújo-Bernardo, C.A. What colour is the corporate social responsibility report? Structural visual rhetoric, impression management strategies, and stakeholder engagement. Corp. Soc. Responsib. Environ. Manag. 2020, 27, 1117-1142. [CrossRef]

28. Campra, M.; Esposito, P.; Lombardi, R. The engagement of stakeholders in nonfinancial reporting: New information-pressure, stimuli, inertia, under short-termism in the banking industry. Corp. Soc. Responsib. Environ. Manag. 2020, 27, 1436-1444. [CrossRef]

29. Ziek, P. Making sense of CSR communication. Corp. Soc. Responsib. Environ. Manag. 2009, 16, 137-145. [CrossRef]

30. Brummett, B. Reading Rhetorical Theory; Harcourt College Publishers: Orlando, FL, USA, 2000.

31. Campbell, C.P. Rhetorical ethos: A bridge between high-context. In The Cultural Context in Business Communication; Niemeier, S., Campbell, C., Dirven, R., Eds.; John Benjamins Publishing Company: Amsterdam, The Netherlands, 1998; pp. 31-48.

32. Burke, K. A Rhetoric of Motives; University of California Press: Berkley, CA, USA, 1969.

33. Elsbach, K.D.; Sutton, R.I. Acquiring organizational legitimacy through illegitimate actions: A marriage of institutional and impression management theories. Acad. Manag. J. 1992, 35, 699-738.

34. Haskins, E.V. Endoxa, epistemological optimism, and Aristotle's rhetorical project. Philos. Rhetor. 2004, 37, 1-20. [CrossRef]

35. Hyde, M.J. The Ethos of Rhetoric; University of South Carolina Press: Columbia, SC, USA, 2004.

36. Zhu, Y. Comparing English and Chinese persuasive strategies in trade fair invitations. Doc. Des. 2000, 2, 2-17.

37. Holt, R.; MacPherson, A. Sensemaking, rhetoric and the socially competent entrepreneur. Int. Small Bus. J. 2010, $28,20-42$. [CrossRef]

38. Aerts, W.; Yan, B. Rhetorical impression management in the letter to shareholders and institutional setting. Account. Audit. Account. J. 2017, 30, 404-432. [CrossRef]

39. Chakorn, O. Rhetorical appeals in Thai annual reports: An investigation of the authority's language in the executive letter during Asia's economic crisis. In Proceedings of the 2008 Association for Business Communication Annual Convention, Lake Tahoe, NV, USA, 30 October-1 November 2008.

40. Green, S. A rhetorical theory of diffusion. Acad. Manag. Rev. 2004, 29, 653-669. [CrossRef]

41. Hyland, K. Exploring corporate rhetoric: Metadiscourse in the CEO's letter. J. Bus. Commun. 1998, 35, 224-244. [CrossRef]

42. Chakorn, O. Persuasive and politeness strategies in cross-cultural letters of request in the Thai business context. J. Asian Pac. Commun. 2006, 16, 103-146. [CrossRef]

43. Ginzel, L.E.; Kramer, R.M.; Sutton, R.I. Organizational impression management as a reciprocal influence process: The neglected role of the organizational audience. In Organizational Identity; Hatch, M.J., Schultz, M., Eds.; Oxford University Press Inc.: New York, NY, USA, 2004; pp. 223-261.

44. Jonall, K.; Rimmel, G. CEO letters as legitimacy builders: Coupling text to numbers. J. Hum. Resour. Costing Account. 2010, 14, 307-328. [CrossRef]

45. Cong, Y.; Freedman, M.; Park, J.D. Tone at the top: CEO environmental rhetoric and environmental performance. Adv. Account. 2014, 30, 322-327. [CrossRef]

46. Burke, K. A Rhetoric of Motives; Prentice Hall: New York, NY, USA, 1950.

47. Bitzer, L.F. The rhetorical situation. Philos. Rhetor. 1968, 1, 1-14.

48. Perelman, C.; Olbrechts-Tytiga, L. The New Rhetoric: A Treatise on Argumentation; Notre Dame University Press: Notre Dame, ID, USA, 1969.

49. Vatz, R.E. The myth of the rhetorical situation. Philos. Rhetor. 1973, 6, 154-161.

50. Cyphert, D. The rhetorical analysis of business speech: Unresolved questions. J. Bus. Commun. 2010, 47, 346-368. [CrossRef]

51. Breton, G.; Cote, L. Profit and the legitimacy of the Canadian banking industry. Account. Audit. Account. J. 2006, 19, 512-539. [CrossRef]

52. Hooghiemstra, R. Corporate communication and impression management-New perspectives why companies engage in corporate social reporting. J. Bus. Ethics 2000, 27, 55-68. [CrossRef]

53. Arndt, M.; Bigelow, B. Presenting structural innovation in an institutional environment: Hospitals' use of impression management. Adm. Sci. Q. 2000, 45, 494-522. [CrossRef]

54. Ogden, S.; Clarke, J. Customer disclosures, impression management and the construction of legitimacy: Corporate reports in the UK privatised water industry. Account. Audit. Account. J. 2005, 18, 313-345. [CrossRef] 
55. Linsley, P.; Kajüter, P.M. Restoring reputation and repairing legitimacy. A case study of impression management in response to a major risk event at Allied Irish Banks plc. Int. J. Financ. Serv. Manag. 2008, 3, 65-82. [CrossRef]

56. Brennan, N.M.; Daly, C.A.; Harrington, C.S. Rhetoric, argument and impression management in hostile takeover defence documents. Br. Account. Rev. 2010, 42, 253-268. [CrossRef]

57. White, R.; Hanson, D. Economic man and disciplinary boundaries. A case study in corporate annual reports. Account. Audit. Account. J. 2002, 15, 450-477. [CrossRef]

58. Driscoll, C.; Crombie, A. Stakeholder legitimacy management and the qualified good neighbor. Bus. Soc. 2001, 40, 442-471. [CrossRef]

59. Prasad, A.; Mir, R. Digging deep for meaning: A critical hermeneutic analysis of CEO letters to shareholders in the oil industry. J. Bus. Commun. 2002, 39, 92-116. [CrossRef]

60. Livesey, S.M. Global warming wars: Rhetorical and discourse analytical approaches to Exxon mobile's corporate public disclosure. J. Bus. Commun. 2002, 39, 117-146. [CrossRef]

61. Milne, M.J.; Patten, D.M. Securing organizational legitimacy: An experimental decision case examining the impact of environmental disclosures. Account. Audit. Account. J. 2002, 15, 372-405. [CrossRef]

62. Nicolo, G.; Zanellato, G.; Manes-Rossi, F.; Tiron-Tudor, A. Corporate reporting metamorphosis: Empirical findings from state-owned enterprises. Public Money Manag. 2021, 41, 138-147. [CrossRef]

63. Cheney, G. The rhetoric of identification and the study of organisational communication. Q. J. Speech 1983, 69, 143-158. [CrossRef]

64. Allen, M.; Caillouet, R. Legitimation endeaours: Impression management strategies used by an organization in crisis. Commun. Monogr. 1994, 61, 44-62. [CrossRef]

65. Ahmad, N.N.N.; Hossain, D.M. Exploring the meaning of climate change discourses: An impression management exercise? Account. Res. J. 2019, 32, 113-128.

66. Brennan, N.M.; Guillamon-Saorin, E.; Pierce, A. Methodological insights: Impression management: Developing and illustrating a scheme of analysis for narrative disclosures-A methodological note. Account. Audit. Account. J. 2009, 22, 789-832. [CrossRef]

67. Neu, D.; Gomez, E.O.; Ponce de Leon, O.G.; Zepeda, M.F. Facilitating globalisation processes: Financial technologies and the World Bank. Account. Forum 2002, 26, 271-290. [CrossRef]

68. Neu, D.; Gomez, E.O.; Graham, C.; Heincke, M. 'Informing' technologies and the World Bank. Account. Organ. Soc. 2006, 31, 635-662. [CrossRef]

69. Schiavo-Campo, S. Potemkin villages: The medium-term expenditure framework in developing countries. Public Budg. Financ. 2009, 29, 1-26. [CrossRef]

70. Van Dijk, T.A. Critical discourse analysis. In The Handbook of Discourse Analysis; Tannen, D., Hamilton, H.E., Schiffrin, D., Eds.; Blackwell: Oxford, UK, USA, 1991; pp. 352-371.

71. Phillips, N.; Laurence, T.B.; Hardy, C. Discourse and institutions. Acad. Manag. Rev. 2011, 29, 635-652. [CrossRef]

72. Fairclough, N. Language and Power; Longman: London, UK, 1989.

73. Phillips, L.; Jorgensen, M.W. Discourse Analysis as Theory and Method; Sage Publications: London, UK, 2002.

74. Fairclough, N. Discourse and Social Change; Blackwell: Oxford, UK, 1992.

75. Wodak, R.; Meyer, M. Methods for Critical Discourse Analysis; Sage: London, UK, 2009.

76. Fairclough, N.; Wodak, R. Critical discourse analysis. In Discourse as Social Interaction; van Dijk, T., Ed.; Sage: London, UK, 1997.

77. Merkl-Davies, D.M.; Koller, V. 'Metaphoring' people out of this world: A Critical Discourse Analysis of a chairman's statement of a UK defence firm. Account. Forum 2012, 36, 178-193. [CrossRef]

78. Fairclough, N.; Graham, P.; Lemke, J.; Wodak, R. Introduction. Crit. Discourse Stud. 2004, 1, 1-7. [CrossRef]

79. Fairclough, N. Analysing Discourse: Text Analysis for Social Research; Routledge: London, UK, 2003.

80. Halliday, M. An Introduction to Functional Grammar; Arnold: London, UK, 1985.

81. Fairclough, N. Critical Discourse Analysis: The Critical Study of Language, 2nd ed.; Longman: London, UK, 2010.

82. Fairclough, N. Critical Discourse Analysis: The Critical Study of Language; Routledge: London, UK, 2013.

83. Krippendorff, K. Content Analysis: An Introduction to Its Methodology, 2nd ed.; Sage Publications: Beverley Hills, CA, USA, 2004.

84. Aerts, W.; Cormier, D. Media legitimacy and corporate environmental communication. Account. Organ. Soc. 2007, 34, 1-27. [CrossRef]

85. Nicolò, G.; Aversano, N.; Sannino, G.; Tartaglia Polcini, P. ICD corporate communication and its determinants: Evidence from Italian listed companies' websites. Meditari Account. Res. 2020. [CrossRef]

86. Botosan, C.A. Disclosure level and the cost of equity capital. Account. Rev. 1997, 72, 323-349.

87. Halliday, M.A.K. Language as Social Semiotic: Social Interpretation of Language and Meaning; Edward Arnold: London, UK, 1978.

88. Florio, C.; Sproviero, A.F. Repairing legitimacy through discourses: Insights from the Volkswagen's 2015 diesel scandal. Meditary Account. Res. 2020. Available online: https://www.emerald.com/insight/content/doi/10.1108/MEDAR-08-2019-0547/full/ html (accessed on 21 March 2021). [CrossRef]

89. Merkl-Davies, D.M.; Brennan, N.M. A conceptual framework of impression management: New insights from psychology, sociology and critical perspectives. Account. Bus. Res. 2011, 41, 415-437. [CrossRef]

90. Widdowson, H.G. Discourse analysis: A critical view. Lang. Literat. 1995, 4, 157-172. [CrossRef]

91. Widdowson, H.G. Reply to Fairclough: Discourse and interpretation. Conjectures and refutations. Lang. Literat. 1996, 5, 57-69. [CrossRef] 
92. Widdowson, H.G. Text, Context, Pretext: Critical Issues in Critical Discourse Analysis; Blackwell: Oxford, UK, 2004.

93. Wodak, R. Critical discourse analysis: Challenges and perspectives. In Critical Discourse Analysis; Wodak, R., Ed.; Sage: Los Angeles, CA, USA, 2013; Volumes XIX-XLIII.

94. Bhatia, V.K. Methodological issues in genre analysis. Hermes J. Lang. Commun. Bus. 2015, 54, 9-20. [CrossRef]

95. Dumay, J.; Cai, L. Using content analysis as a research methodology for investigating intellectual capital disclosure: A critique. J. Intellect. Cap. 2015, 16, 121-155. [CrossRef] 